\title{
Factors Affecting Vehicle Tax Compliance Paying
}

\author{
Joni, S.S.T, BKP \\ Institut STIAMI \\ DOI: 10.29322/IJSRP.11.07.2021.p11585 \\ http://dx.doi.org/10.29322/IJSRP.11.07.2021.p11585
}

\begin{abstract}
The purpose of this study was to determine the effect of taxpayer awareness, understanding of taxpayers, service quality, and tax sanctions on taxpayer compliance in partially paying Motor Vehicle Tax in XYZ City. The method used in sample selection is simple random sampling method, data is collected by distributing a minimum of 100 questionnaires. Where in this study, the samples were people whom the researcher met randomly at the research location. The data analysis method used in this research is multiple linear regression analysis. The purpose of multiple linear regression analysis is to determine the magnitude of the influence of the independent variable $(\mathrm{X})$ on the dependent variable (Y). Based on the results of the analysis, it shows that: (1) taxpayer awareness does not have a significant effect on taxpayer compliance in paying motorized vehicle tax in XYZ City; (2) understanding of taxpayers has a positive and significant effect on taxpayer compliance in paying motorized vehicle taxes in XYZ City; (3) service quality has a positive and significant effect on taxpayer compliance in paying motor vehicle tax in XYZ City; and (4) tax sanctions have no significant effect on taxpayer compliance in paying motor vehicle tax in XYZ City.
\end{abstract}

Index Terms- Taxpayer Compliance, Taxpayer Awareness, Taxpayer Understanding, Service Quality, Tax Sanctions.

\section{INTRODUCTION}

$\mathrm{L}$ ocal taxes According to Law Number 28 of 2009 are mandatory contributions to regions owed by private persons or entities that are compelling under the law, without receiving direct compensation and used for regional needs for the greatest prosperity of the people. This regional tax can come from the regional tax itself or the provincial tax which will be submitted to each region to meet regional needs in the context of prospering the people.

Taxes can be interpreted as a source of funds from a country to overcome various problems such as social problems, increase welfare, prosperity and become a social contract between the government and its citizens.Susilawati, KE, \& Budiartha, K. (2013) argue that the factors that influence a country's tax revenue is economic growth. Economic growth will increase people's income which of course will have a direct effect on the ability of the community financially to pay taxes. In the research of Wardani, D. K., \& Rumiyatun, R. (2017), the factors that influence a country's tax revenue include the level of taxpayer compliance in that country. If the public is more aware and obedient to tax regulations, it will certainly have an impact on increasing domestic tax revenue. The greater the amount of tax received, the more profitable the country Ilhamsyah, R. (2016). In city x itself, local taxes contribute a sizeable amount to local revenue. One type of local tax revenue includes motorized vehicle tax. Motor vehicle tax collection is a type of collection that has long been carried out by the government. This tax greatly influences local sources of revenue, which is useful for financing the implementation of routine duties of the local government (Wuryanto, L. , Sadiati, U., \& Afif, MN, 2019). One of the regional development in each regency / city is financed through funds obtained through motor vehicle taxes. So the collection of this tax revenue needs to be optimized as well as possible. The rapid development in the automotive world has resulted in the rapid turnover of motorized vehicles. This is evidenced by the rapid development of motor vehicle dealerships with the increasingly varied types of motorized vehicles available. The following is data on the growth in the number of motorized vehicles for city X in 2017-2019.

Table 1. Number of Motorized Vehicles Registered at SAMSAT City X in 2017-2019

\begin{tabular}{llllll}
\hline Year & Two wheels & $\%$ & Four Wheels & $\%$ & Amount \\
\hline 2017 & 360.845 & $79.00 \%$ & 96.756 & $21.15 \%$ & 367.664 \\
2018 & 390.132 & $80.12 \%$ & 102.756 & $20.44 \%$ & 446.065 \\
2019 & 471.456 & $81.02 \%$ & 104.856 & $23.00 \%$ & 475.303 \\
\hline
\end{tabular}

Source: SAMSAT City X, 2019.

In the table above, it can be seen that the number of motorized vehicles registered in Kota $\mathrm{X}$ in 2017 the number of two-wheeled vehicles was 360,845 , the number of four-wheeled vehicles was 96,756. In 2018 there was an increase in the number of two-wheeled vehicles by 390,132 , the number of four-wheeled vehicles as much as 102,756 , then for 2019 there was an increase in the number of two-wheeled vehicles by 471,456 , the number of four-wheeled vehicles by 104,856 . The number of motorized vehicles registered in Samsat City $\mathrm{X}$ is increasing from year to 
year. the number of people who pay their motor vehicle tax. This can be seen in the following table:

Table 2. Number of Motor Vehicles Paying Taxes in 2017-2019

\begin{tabular}{lllll}
\hline Year & $\begin{array}{l}\text { Number of vehicles } \\
\text { Motorized }\end{array}$ & $\begin{array}{l}\text { Number of vehicles } \\
\text { Who Pay Taxes }\end{array}$ & Difference & $\%$ \\
\hline 2017 & 557.664 & 395.467 & 162.197 & $36.44 \%$ \\
2018 & 693.065 & 499.812 & 193.253 & $40.19 \%$ \\
2019 & 576.303 & 427.499 & 148.804 & $23.37 \%$ \\
\hline
\end{tabular}

Source: SAMSAT City X, 2019.

In the table above, it can be seen that the number of motorized vehicles paying taxes in 2017 was 557,664, the number of vehicles paying taxes was 395,467 , and the difference was 104,345. In 2018 the number of motorized vehicles was 693,065, the number of vehicles paying taxes was 499,812 , and the difference was 72,313 .
Table 2. shows that there is a difference between the number of registered motor vehicles and the number of vehicles paying motor vehicle tax. Furthermore, for the realization of Motor Vehicle Tax Revenues based on the data table below.

Table 3. Realization of Motor Vehicle Tax Revenues in 2017-2019

\begin{tabular}{cllll}
\hline Year & Target & Tax-Paying Vehicles & Realization & $\%$ \\
\hline 2017 & 243.063 .000 .000 & 395.467 & 255.030 .055 .600 & $106.39 \%$ \\
2018 & 253.886 .000 .000 & 499.812 & 269.066 .926 .000 & $108.48 \%$ \\
2019 & 284.154 .000 .000 & 427.499 & 297.438 .259 .000 & $109.87 \%$ \\
\hline
\end{tabular}

Source: SAMSAT City X, 2019.

Based on the Motor Vehicle Tax Revenue Realization data in the table above, it shows that motor vehicle tax revenue from 2017 to 2019 at City Samsat x always reaches the target from year to year. In 2017, the target reached was 243,063,000,000, motorized vehicles paying taxes were 395,456 , the number of realized motor vehicle taxes was $255,030,055,600$, indicating the percentage of the target achieved was $106.39 \%$. In 2018, the target reached was $253,886,000,000$, motor vehicles that paid taxes were 499,812 , the number of realized motor vehicle taxes was $269,066,926,000$, indicating the percentage of the target achieved was $108.48 \%$.

Based on the three tables, it can be seen that the data on the number of motorized vehicles paid for and those registered do not match. This means that there are still 72,313 taxpayer motor vehicles whose taxes were not paid in 2019 , this means that the level of compliance with motor vehicle taxpayers is still relatively low. Although if seen every year the tax revenue increases, the number of taxpayers who pay with those who are registered is not comparable.

There are several factors that can affect taxpayer compliance, the first factor is Tax knowledge is a basic understanding for taxpayers about the correct tax laws, laws and procedures. According to Putra and Jati (2017), tax knowledge and understanding have a positive effect on taxpayer compliance. Taxpayer understanding of tax regulation is an internal cause because it is under the control of the taxpayer itself. Different levels of knowledge and understanding of taxpayers will affect the assessment of each taxpayer to behave obediently in carrying out tax obligations. A high level of understanding of the taxpayer will make taxpayers choose to behave obediently in carrying out their tax obligations.

The second factor Tax socialization is also one of the factors that causes taxpayers to not comply with paying their taxes. According to Ilhamsyah (2016) the process of tax socialization and counseling is expected to have a positive impact on public tax knowledge so that it can also increase the number of taxpayers, increase taxpayer compliance, which in turn increases state revenue from the public sector. This socialization is needed so that taxpayers can increase their knowledge of taxation, and know the role and function of taxes.

The third factor in the implementation of E-Samsat is the West Java Bapenda's effort to provide the best service to the community, in an effort to optimize the level of compliance to make it easier for taxpayers to pay their taxes. The E-Samsat service is expected to provide motor vehicle tax payment services and the validation of STNK by way of payment through Bank ATMs that have collaborated throughout Indonesia. The West Java E-Samsat service is a service that provides benefits and convenience, payments made directly by taxpayers via ATM, are expected to avoid brokering, eliminate corruption in tax revenue, correct calculation of taxes to be paid, and of course provide comfort for vehicle taxpayers. motorized. With this service, it can make it easier for taxpayers to pay their taxes without having to return to their area of origin to take care of the vehicle tax.

The difference in the results of the above research makes researchers motivated to reexamine taxpayer compliance. The 
difference between this study and previous studies is that the researcher chooses three independent variables, namely Tax Knowledge, Tax Socialization and the Application of E-Samsat as variables that affect individual taxpayers.

Seeing this reality, it is expected that government revenue from motorized vehicle taxes can increase in line with the increase in the number of motorized vehicle purchases. Factors that can increase taxpayer compliance include taxpayer awareness, moral obligations, service quality, and tax sanctions. self assessment system carries the mission and consequences of changing attitudes (awareness) of society to pay taxes voluntarily (Darmayanti, 2004). The implementation of a self-assessment system in the correctness of tax payments according to Pancawati (2011) depends on the honesty of taxpayers themselves in reporting their tax obligations. Taxpayer awareness can be seen from the seriousness and desire of taxpayers to fulfill their tax obligations which is shown in the taxpayer's understanding of the tax function and the seriousness of the taxpayer. in paying and reporting taxes. Moral obligation is another effort to maximize taxpayer compliance.

According to Ajzen (2002) ethics, the principle of life, guilt is a moral obligation that every person has in doing something. Where this can be related to the fulfillment of taxpayer compliance in paying PKB. This is in line with research conducted by Ho (2004) where the level of tax compliance will be higher when the taxpayer has a stronger moral obligation. Providing good service can increase taxpayer compliance in paying taxes voluntarily. According to Palda and Hanousek (2002) the willingness of taxpayers to pay taxes is largely influenced by the quality of services provided by the government. Feelings of pleasure and satisfaction with services provided by the government can trigger motivation and compliance for taxpayers which ultimately can increase local revenue. Tax sanctions that will be received by taxpayers are another factor that can affect the increase in motor vehicle taxpayer compliance. Tax audits and sanctions / fines imposed by tax authorities are the main motivators of taxpayer compliance (Witte and Woodbury, 1985).

Ali (2001) in his research also stated that auditing and sanctions are effective policies to prevent non-compliance. To prevent non-compliance and to encourage taxpayers to fulfill their tax obligations, strict sanctions must be imposed in order to promote fairness and effectiveness of the tax system (Webley et.al, 1991). Based on the above problems, the main problem in this study is whether the taxpayer's awareness, moral obligations, service quality and tax sanctions affect taxpayer compliance in paying motor vehicle taxes.

\section{LITERATURE REVIEW}

\section{Tax Knowledge}

The definition of tax knowledge according to Wardani \& Rumiyatun (2017) is a basic understanding for taxpayers regarding the correct tax laws, laws and procedures. Through formal education and non-formal education can increase knowledge of taxation. Formal education is a structured and tiered path of education consisting of basic education, secondary education to higher education (Wardani and Asis, 2017). Meanwhile, nonformal education is a path of education outside formal education.
Examples: course institutions, community organizations, and others.

\section{Tax Socialization}

Tax socialization according to Rusmayani and Supadmi (2017) is an effort made by the Directorate General of Taxes to provide knowledge to the public and especially taxpayers to know everything about taxation, both tax regulations and procedures through appropriate methods.

Meanwhile, according to Cong and Agoes (2019), tax outreach activities can be carried out using two methods, namely direct socialization and indirect socialization. Direct socialization is taxation socialization activity by interacting directly with taxpayers. Forms of direct socialization that have been held include Tax Goes To School / Tax Goes To Campus, tax competitions, and others. Meanwhile, indirect socialization is the activity of tax socialization to taxpayers without direct interaction. Indirect forms of socialization include the internet, distribution of tax manuals, broadcasting via television or radio.

\section{Taxpayer Compliance}

The definition of taxpayer compliance according to the Decree of the Minister of Finance No.554 / KMK / .04 / 200 is the action of a taxpayer in fulfilling his tax obligations in accordance with the provisions of laws and regulations for implementing taxation in force in a country. According to Rusandi et al (2018) Tax Compliance is: " Related to activities to comply with tax regulations, which include: Administration, bookkeeping, tax withholding / collection, deposits, reporting, providing data for tax audit purposes and so on. In general, tax regulations will be obeyed by taxpayers if the cost to fulfill them (compliance cost) is relatively cheap.

Taxpayer awareness is a condition in which taxpayers understand and implement taxation rules properly and voluntarily. If the understanding and implementation of tax obligations is getting better, the level of awareness of taxpayers will be higher so that it is expected to increase tax compliance (Muliari and Ery, 2011).

Based on the results of research by Diatnyani (2010), it is evident that taxpayer awareness has a positive and significant effect on individual taxpayer reporting compliance. In addition, Yudha (2011) also proves that taxpayer awareness has a positive effect on taxpayer compliance in paying the Motor Vehicle Title Fee (BBNKB) tax. Based on the literature and previous research results, the hypothesis proposed in this study are as follows:

H1: Taxpayer awareness has a positive effect on taxpayer compliance in paying Motor Vehicle Tax at the SAMSAT XX Office Moral obligation is an individual norm that a person has in carrying out something, such as ethics and principles of life (Ajzen, 2002). This will be related to the fulfillment of tax obligations for taxpayer compliance in paying motorized vehicle taxes. Based on research conducted by Pratama (2008), moral obligation has a positive and significant effect on corporate taxpayer reporting compliance. In addition, Mustikasari (2007) in his research entitled Empirical Study of Corporate Taxpayer Compliance in Processing Industry Companies in Surabaya, moral obligation has a positive and significant effect on corporate taxpayer compliance. Where if the tax professional has a high moral obligation, the intention of tax non-compliance is low.

This publication is licensed under Creative Commons Attribution CC BY

http://dx.doi.org/10.29322/IJSRP.11.07.2021.p11585

WWW.ijsrp.org 
Based on the literature and previous research results, the hypothesis proposed in this study is as follows:

$\mathrm{H} 2$ : Moral obligation has a positive effect on taxpayer compliance in paying Motorized Vehicle Tax at the SAMSAT XX Office. Taxpayer satisfaction as a customer can be increased through improving the quality and quantity of services. This is expected to increase taxpayer compliance in the field of taxation (Supadmi, 2009). Krisna (2011) ) prove that service quality has a positive and significant effect on taxpayer compliance in paying Motor Vehicle Tax at the SAMSAT Jembrana Office. Nugroho and Sumadi (2005) also prove that service quality has a significant effect on income taxpayer satisfaction at KPP Yogyakarta One. Based on the literature and the results of previous studies, the hypothesis proposed in this study are as follows:

H3: Service quality has a positive effect on taxpayer compliance in paying Motorized Vehicle Tax at the SAMSAT XYZ Office Tax sanctions are a guarantee that the provisions of taxation laws and regulations will be obeyed, in other words, tax sanctions are a deterrent so that taxpayers do not violate taxation norms (Mardiasmo, 2009 : 47). According to Nugroho and Sumadi (2006), taxpayers will fulfill their tax obligations if they view that tax sanctions will be more detrimental to them. Agus (2006) proved through his research that tax sanctions have a positive effect on compliance

\section{Hypothesis Development}

The Influence of Tax Knowledge on Taxpayer Compliance in Paying Motor Vehicle Taxes

Tax knowledge is the basic understanding of taxpayers in fulfilling their tax obligations (Lasmana and Wiryanti, 2018).
Without any knowledge of that taxation owned by the taxpayer, the taxpayer will not want to pay his taxes. So with the knowledge that the taxpayer has, the taxpayer will know more about the importance of paying taxes and what benefits will be obtained when the taxpayer pays his taxes. Attribution theory is relevant to explain this hypothesis. Tax knowledge is an internal factor in attribution theory, because knowledge is the basis for taxpayers to understand the importance of taxation (Melani and Susanti, 2018).

\section{The Effect of Taxation Socialization on Taxpayer Compliance in Paying Motor Vehicle Taxes.}

Tax dissemination is an effort made to the public and taxpayers regarding tax regulations and taxation procedures. When the public and taxpayers know the tax regulations and procedures, the taxpayer compliance in paying their taxes will be even higher. This attribution theory is relevant to explain this hypothesis. Tax socialization is an external factor of attribution theory. Because with the socialization of taxation, it can increase or foster knowledge about taxation to people who already know taxation and those who don't.

$\mathrm{H} 2$ : It is suspected that taxation socialization has a positive and significant effect partially on the compulsory compliance of motorbike taxpayers.

\section{Operationalization of Variables}

Independent variables (independent variables) in this study are Tax Knowledge (X1), Tax Socialization (X2). Dependent variable in this research is (dependent variable) Motor Vehicle Taxpayer Compliance.

Table 4. Operationalization of Variables

\begin{tabular}{|c|c|c|c|c|}
\hline No & Variable & Operational definition & Indicator & Scale \\
\hline 1. & $\begin{array}{l}\text { Tax Knowledge } \\
\text { (X1) }\end{array}$ & $\begin{array}{l}\text { Tax knowledge is the basic } \\
\text { understanding of taxpayers in } \\
\text { fulfilling their tax obligations. } \\
\text { With knowledge } \\
\text { taxpayers have, then they will } \\
\text { know more about the } \\
\text { importance of paying taxes and } \\
\text { what benefits will be obtained } \\
\text { when taxpayers pay their taxes. } \\
\text { (Melani and Susanti, 2018) }\end{array}$ & $\begin{array}{l}\text { 1. Meet tax obligations } \\
\text { 2. Pay taxes on time } \\
\text { 3. Taxpayers know } \\
\text { 4. Taxpayers know the due date } \\
\text { (Melani and Susanti, 2018) }\end{array}$ & Ordinal \\
\hline 2. & $\begin{array}{l}\text { Tax } \\
\text { Socialization } \\
(\mathrm{X} 2)\end{array}$ & $\begin{array}{l}\text { Tax socialization is an effort } \\
\text { made to the public and } \\
\text { taxpayers regarding tax } \\
\text { regulations regarding tax } \\
\text { regulations and taxation } \\
\text { procedures. After tax } \\
\text { socialization is held, the public } \\
\text { or taxpayers should be more } \\
\text { obedient to pay their taxes. } \\
\text { (Melani and Susanti, 2018) }\end{array}$ & $\begin{array}{l}\text { 1. Socialization from officers. } \\
\text { 2. Socialization of mass media } \\
\text { taxation. } \\
\text { 3. Socialization material is easy } \\
\text { to understand. } \\
\text { 4. Increase Taxpayer } \\
\text { knowledge. } \\
\text { 5. Socialization is effective and } \\
\text { right on target. (Melani and } \\
\text { Susanti, 2018) }\end{array}$ & Ordinal \\
\hline 3. & $\begin{array}{l}\text { Motor Vehicle } \\
\text { Taxpayer } \\
\text { Compliance (Y) }\end{array}$ & $\begin{array}{l}\text { Taxpayer compliance is where } \\
\text { the taxpayer fulfills his tax } \\
\text { obligations and implements } \\
\text { taxation rights properly, is } \\
\text { obedient, and obedient to pay }\end{array}$ & $\begin{array}{l}\text { 1. Taxpayers register } \\
\text { themselves. } \\
\text { 2. Taxpayers register their own } \\
\text { vehicles. }\end{array}$ & Ordinal \\
\hline
\end{tabular}




\begin{tabular}{|l|l|l|}
\hline & $\begin{array}{l}\text { his taxes and is not late to } \\
\text { report his taxes. (Melani and } \\
\text { Susanti, 2018) }\end{array}$ & $\begin{array}{l}\text { 3. Fulfill tax obligations in } \\
\text { accordance with applicable } \\
\text { regulations. } \\
4 . \text { Pay taxes on time a. } \\
5 . \text { Taxpayers meet the } \\
\text { requirements in paying their } \\
\text { taxes. } \\
\text { 6. Taxpayers can know the due } \\
\text { date of payment. } \\
\text { (Melani and Susanti, 2018) }\end{array}$ \\
\hline
\end{tabular}

\section{RESEARCH METHODOLOGY}

The data used in this study are primary data obtained through the results of filling out questionnaires by respondents. Where the population of this study is all motor vehicle taxpayers registered at the SAMSAT XYZ Office. The sampling method used in this study is accidental sampling where the criteria for respondents are all motor vehicle taxpayers registered at the XYZ City SAMSAT Office up to the period 31 December 2019, owners of black plate vehicles and are direct motor vehicle taxpayers are not brokers. Based on these criteria, a total population of 940,472 and a sample size of 100 were obtained using the Slovin formula with a critical value of 10 percent. The variables used in this study were the dependent variable and the independent variable. Where the dependent variable in this study was taxpayer compliance in pay motor vehicle tax, while the independent variables are taxpayer awareness, moral obligation, service quality and tax sanctions. The initial test in this study is the classic assumption test consisting of normality test, multicollinearity test and heteroscedasticity test to find out that the data is normally distributed, there is no correlation between variables and there is no similarity of variants. Furthermore, multiple linear regression analysis is carried out to get an overview of the influence of the variables. independent of the dependent variable. This analysis was performed using the SPSS 13.0 for Windows program. The multiple linear regression model is shown by the following equation.

$\mathrm{Y}=\alpha+\beta 1 \mathrm{X} 1+\beta 2 \mathrm{X} 2+\beta 3 \mathrm{X} 3+\beta 4 \mathrm{X} 4+\mathrm{e}$

(1) Information: $Y=$ Taxpayer compliance in paying taxes

Motorized Vehicle (PKB)

$\alpha=$ Constanta

$\beta 1, \beta 2, \beta 3, \beta 4=$ Regression coefficient

$=$ Confounding variable

$\mathrm{X} 1=$ Taxpayer awareness

$\mathrm{X} 2=$ moral obligation

$\mathrm{X} 3$ = Quality of service

$\mathrm{X} 4=$ Tax sanctions

Furthermore, the hypothesis test is carried out which consists of the $\mathrm{F}$ statistical test and the $\mathrm{t}$ statistical test. The $\mathrm{F}$ statistical test is used to determine the effect of the independent variables simultaneously on the dependent variable. While the $t$ statistical test is used to determine whether all independent variables individually affect taxpayer compliance in paying motorized vehicle taxes at the SAMSAT XYZ office.

\section{Sampling}

The population of this research is the motorized vehicle taxpayers in SAMSAT XYZ City, amounting to 400 respondents. For sample selection using total sampling so that the entire population is sampled. Respondents in this study were motorized vehicle taxpayers with the calculation of the Slovin formula was 300 people.

\section{Instrument Testing}

The research instrument is used to carry out measurements with the aim of producing accurate quantitative data and expressed in numbers, so before testing it needs to be processed using a Likert scale first, Sugiyono (2016) states that the Likert scale is a scale that can be used to measure attitudes, opinions and a person's perception of a particular object or phenomenon, which is recorded from an ordinal scale.

\section{Data analysis method}

Multiple regression model is an analysis tool for forecasting the effect of two dependent variables to prove the presence or absence of a functional relationship or a causal relationship between two or more dependent variables:

$\mathrm{Y}=\mathrm{a}+\beta 1 \mathrm{X} 1+\beta 2 \mathrm{X} 2+\mathrm{e}$

Information:

$\mathrm{Y}=$ Motor Vehicle Taxpayer Compliance

$\mathrm{a}=$ Constant Value

$\mathrm{X} 1=$ Tax Knowledge

$\mathrm{X} 2=$ Tax Socialization

\section{Simultaneous Test (f-test)}

The F statistical test or simultaneous regression coefficient test is used to determine whether all independent variables (Tax Knowledge, Tax Socialization) included in the model have a simultaneous influence on the dependent variable (Taxpayer Compliance).

\section{Partial Test (t-test)}

The $t$ test is intended to determine the effect of the independent variable (Tax Knowledge, Tax Socialization).

$\varepsilon=$ Error

$\beta 1=$ Variable regression coefficient

$\mathrm{X} 1 \beta 2=$ variable regression coefficient $\mathrm{X} 2$

\section{Multiple Correlation Coefficient}

The correlation coefficient is a number that shows the direction and strength of the relationship between the independent variable and the dependent variable. The formula according to Sugiyono (2016). 


\section{Coefficient of Determination (R2)}

Sugiyono (2016) states that the coefficient of determination ( $\mathrm{R}$ Square / R2) is used to determine the percentage of the contribution of the influence of the independent variables together on the dependent variable. The formula used to measure the coefficient of determination is as follows:

$\mathrm{KD}=\mathrm{r} 2 \times 100 \%$

Information:

$\mathrm{KD}=$ coefficient of determination

r2 = Correlation Coefficient to the dependent variable (Taxpayer Compliance) individually or partially.

\section{RESULTS AND DISCUSSION}

\section{Result}

This research was conducted at SAMSAT City X with a total of 300 respondents, the respondents in this study were motorized vehicle taxpayers. Data collection was done by distributing questionnaires, researchers distributed 300 questionnaires with a total of 300 questionnaires returned. Of the number of questionnaires returned, all questionnaires were completely filled and not damaged.

\section{Reliability Test}

After testing the validity, then the reliability testing is carried out. Reliability test is used to find out whether the data collection tool used shows the level of accuracy, accuracy, stability and consistency of the tool, and the results of these measurements will remain consistent when re-measured. Reliability test results show how much consistency and trustworthiness the results of respondents' answers to the instruments / statements given. To measure the consistency of the intervals of using the instrument, Cronbach Alpha was used. To find out that all variables were said to be reliable, the average Cronbach Alpha value had to be greater than or equal to 0.6.

Table 5. Reliability Test Table

\begin{tabular}{|l|l|l|l|}
\hline Variable & & & Information \\
\hline Tax Knowledge & 0,753 & 0,6 & Reliable \\
\hline Tax Socialization & 0,821 & 0,6 & Reliable \\
\hline $\begin{array}{l}\text { Motor vehicle taxpayer } \\
\text { compliance }\end{array}$ & 0,913 & 0,6 & Reliable \\
\hline
\end{tabular}

Source: Processed data, 2021

Based on the table above, all statements from the Tax Knowledge variable, the Tax Socialization variable, and the dependent variable, namely Motor Vehicle Taxpayer Compliance, are declared reliable because Cronbach's Alpha each statement is greater than $r$ Critical.

\section{Discussion}

The results of the $\mathrm{F}$ test with a positive number indicate that there is a positive and significant effect simultaneously on Taxation Knowledge, Taxation Socialization and on Motor Vehicle Taxpayer Compliance, indicating that Motor Vehicle Taxpayer Compliance can be measured from the extent to which Tax Knowledge is applied, Tax Socialization. Knowledge of

This publication is licensed under Creative Commons Attribution CC BY.

http://dx.doi.org/10.29322/IJSRP.11.07.2021.p11585 taxation and good and effective tax dissemination will increase the level of motor vehicle taxpayer compliance. From the test results obtained Fcount $>$ Ftable $(74.563>4.39)$ with a significance value of $\mathrm{F}$ of $0.00<0.05$. This means that $\mathrm{Ho}$ is rejected and $\mathrm{Ha}$ is accepted. This condition means that Tax Knowledge and Taxation Socialization simultaneously have a significant effect on Motor Vehicle Taxpayer Compliance.

\section{The Influence of Knowledge on Taxation}

Based on the test results, the tax knowledge variable partially has a significant and significant effect on motor vehicle taxpayer compliance. It can be seen from the results of the $t$ test that the value for Tax Knowledge was 2.012, which was greater than the $\mathrm{t}$-value, which was 1.965 , and was strengthened by the results of the profitability of 0.001 which was smaller than the profitability value of $a=0.05$. These results illustrate that the Taxation Knowledge variable partially affects Motor Vehicle Taxpayer Compliance. With a choice of respondents' answers that are evenly distributed to all indicators of the questionnaire statement: Knowing rights and obligations in taxation, knowing motor vehicle tax payment procedures, fulfilling all required tax payment requirements, obtaining information on motor vehicle tax calculations clearly and understanding the deadline for paying motor vehicle taxes . Respondents' responses to questions indicate the value of interpretation strongly agrees. This result is in accordance with research conducted by Danarsi and Subroto (2017) which states that the taxpayer knowledge variable has a positive effect on motor vehicle taxpayer compliance.

\section{The Influence of Tax Socialization}

Based on the results of testing the tax socialization variables partially and significantly affects motor vehicle taxpayer compliance. This means that the higher the socialization of taxation, the higher the level of compliance of motor vehicle taxpayers. This can be seen from the t test conducted, the tax socialization value is 6.499 , while the $\mathrm{t}$ table value is 1.965 , and is strengthened by the results of the profitability value of 0.002 which is smaller the profitability of $a=0.05$. These results illustrate that the taxation socialization partially affects motor vehicle taxpayer compliance. With the choice of respondents' answers that are evenly distributed on all indicators of the questionnaire statement: tax officials often do tax socialization, often see advertisements about the importance of paying taxes both in print and electronic media, can understand any information provided by tax officers at the time of socialization, my knowledge of taxation increases after the socialization, the socialization carried out by tax officials is as effective and right on target. Respondents' responses regarding the statement show very agreeable results. These results are in accordance with research conducted by Ilhamsyah (2016) which states that tax socialization has an effect on taxpayer compliance.

\section{CONCLUSIONS}

Characteristics of respondents were dominated by males, as many as 279 respondents, with respondents aged 31-40 years, namely 144 respondents, using two-wheeled vehicles, namely 269 respondents, with undergraduate education (S1) as many as 95 respondents, and the average type of work in the dominance of 
swata employees, namely 158 respondents, in paying motorized vehicle taxes, namely as many as 300 respondents. Tax Knowledge and Taxation Socialization simultaneously have a significant effect on Motor Vehicle Taxpayer Compliance. Knowledge of Taxation, and Tax Socialization partially have a significant effect on Motor Vehicle Taxpayer Compliance.

\section{REFERENCES}

[1] Al Anti, F. (2016). Factors Affecting Taxpayer Compliance in Paying Motor Vehicle Taxes. Journal of Scientific Study of Accounting, Faculty of Economics UNTAN (KIAFE), 7 (1).

[2] Analysis of Factors Affecting Motor Vehicle Taxpayer Compliance at the Joint Office of the Samsat Tabanan. E-Journal of Accounting, 557-587.

[3] Arifin, A. F. (2016). The Influence of the Modernization of the Tax Administration System, Tax Awareness, Tax Sanctions and Fiscal Services on Individual Taxpayer Compliance at Kpp Pratama. Perbanas Review, 1 (01).

[4] Cong, J., \& Agoes, S. (2019). Factors Affecting Taxpayer Compliance in Paying Motor Vehicle Taxes. Journal of Accounting Paradigm, 1 (2), 292299.

[5] Danarsi, S. N., \& Subroto, H. (2017). Factors Affecting Taxpayer Compliance In Paying Car Tax With Progressive Tax In The City Of Surakarta. Journal of Accounting and Tax, 18 (01).

[6] Ilhamsyah, R. (2016). The Influence of Taxpayers' Understanding and Knowledge of Tax Regulations, Taxpayer Awareness, Service Quality, and Tax Sanctions on Motor Vehicle Taxpayer Compliance (SAMSAT Study of Malang City). Taxation Student Journal, 8 (1).

[7] Ketut, A. R. S. P. I. (2013). Factors affecting taxpayer compliance in paying motor vehicle tax in Denpasar. E-Journal of Accounting, 2 (3), 661-677.

[8] Lasmana, A., \& Wiryanti, D. A. (2018). Factors Affecting Taxpayer Compliance At Kkp Pratama Majalaya. ACCOUNT JOURNAL, 3 (2), 1-10.

[9] Melani, M. M., \& Susanti, L. (2018). Analysis of Factors Affecting Taxpayer Compliance (Case Study at Kpp Pratama Sukabumi). ACCOUNTS JOURNAL, 4 (1), 47-60.

[10] Mukmin, M. N., \& Maemunah, S. (2019). Village Government Fund Management: A Study in Babakan Madang, Sukaraja and Ciawi Districts. Accountida's Journal, 4 (2), 73-85.
[11] Putra, I. M. A. D., \& Jati, I. K. (2017). Analysis of Factors Affecting Motor Vehicle Taxpayer Compliance at the Joint Office of SAMSAT Tabanan. EJournal of Accounting, 18 (1), 557-587.

[12] Rusandi, M., Malisan, L., \& Oktavianti, B. (2018). Analysis of Factors Affecting Taxpayer Compliance in Paying Taxes. Mulawarman Journal of Accounting (JIAM), 2 (3).

[13] Rusmayani, N. M. L., \& Supadmi, N. L. (2017). The Influence of Socialization, Knowledge, Sanctions and Service Quality on Motor Vehicle Taxpayer Compliance. E- Journal of Accounting, 173-201.

[14] Sari, R. V. Y., \& Susanti, N. (2014). Factors Affecting Taxpayer Compliance in Paying Motor Vehicle Tax (PKB) at the Provincial Revenue Service Unit (UPPP) of Seluma Regency. ECOMBIS REVIEW: Scientific Journal of Economics and Business, 2 (1).

[15] Sugiyono.2016. Quantitative, Qualitative, and Combined Research Methods (Mixed Methods). Bandung: Alfabeta.

[16] Susilawati, K. E., \& Budiartha, K. (2013). The influence of taxpayer awareness, tax knowledge, tax sanctions and public service accountability on motor vehicle taxpayer compliance. E-Journal of Accounting, 4 (2), 345-357.

[17] Wardani, D. K., \& Asis, M. R. (2017). The Influence of Taxpayer Knowledge, Taxpayer Awareness, and the Samsat Corner Program on Motor Vehicle Taxpayer Compliance. DEWANTARA ACCOUNTING, 1 (2), 106116.

[18] Wardani, D. K., \& Rumiyatun, R. (2017). The Influence of Taxpayer Knowledge, Taxpayer Awareness, Motor Vehicle Tax Sanctions, and the Samsat Drive Thru System on Motor Vehicle Taxpayer Compliance. Journal of Accounting, 5 (1), 15-24.

[19] Wardani, D. K., \& Rumiyatun, R. (2017). The Influence of Taxpayer Knowledge, Taxpayer Awareness, Motor Vehicle Tax Sanctions, and the Samsat Drive Thru System on Motor Vehicle Taxpayer Compliance. Journal of Accounting, 5 (1), 15-24.

[20] Wuryanto, L., Sadiati, U., \& Afif, M. N. (2019). Factors Affecting Taxpayer Compliance in Paying Motor Vehicle Taxes. ACCOUNTS JOURNAL, 5 (2), 15-31.

\section{AUTHORS}

First Author - Joni, S.S.T, BKP, Institut STIAMI, joni.jovindo@gmail.com 